\title{
LIKELY IMPACTS OF HUDHUD ON THE ENVIRONMENT OF VISAKHAPATNAM
}

\author{
S. Ramakrishna Rao \\ Director, CPC, Gitam University, Professor Civil Dept, Andhra University (Retd)
}

\begin{abstract}
Hudhud cyclone has created havoc in north coastal districts of Andhra Pradesh on $12^{\text {th }}$ October, 2014 and caused extensive damage specially to Visakhapatnam district in general and in particular to Visakhapatnam city. The damage is mainly to the tree cover and consequential destruction of the power lines leading to the colossal loss to the power sector. In these circumstances of great loss of tree cover and change in the local conditions the city might experience different impacts on the local life and environment. This paper summarizes the possible detrimental impacts of Hudhud on the environment of Visakhapatnam and also suggests possible measures to be followed so as to minimize the detrimental effects. These measures / actions prompted cover different fields including air and water environmental as well as solid waste management.
\end{abstract}

$* * *$

Hudhud cyclone has created havoc in north coastal districts of Andhra Pradesh on $12^{\text {th }}$ October, 2014 and caused extensive damage specially to Visakhapatnam district in general and in particular to Visakhapatnam city. The damage is mainly to the tree cover and consequential destruction of the power lines leading to the colossal loss to the power sector. Till today Visakhapatnam has not witnessed the direct entry of the eye of the storm reaching the land and hence damage was beyond the expectation. So far it is heartening to note that the Andhra Pradesh government's fore sight helped the people in controlling the damage to life and assets.

The regulation of traffic on the previous day of the hudhud on the national highway and passing of the information to the nook and corners of the mandals has saved lot of loss of life including that of the animals. The disconnection of power on the night previous to the storm till the passing off, has also saved the life of stray animals and birds. All said and done the measures taken by the Andhra Pradesh state government under the leadership of sri. N. Chandra Babu Naidu and his council of ministers is most appreciable apprehending the major disaster and preventing the colossal damage to the minimum possible extent. The rehabilitation of the people and resumption of services of different sectors after the disaster is the untiring efforts of the administration and local elected representatives taking the reviews from the honorable chief minister who was guiding force, is much laudable.

In these circumstances of great loss of tree cover and change in the local conditions the following impacts may occur on the local life and environment. Certain suggestions are also given here under for the benefit of the locals and to the administration to rebuild the environment.

1. The loss of green cover:

A) The trees which are functional in absorbing $\mathrm{CO}_{2}$ and release $\mathrm{O}_{2}$ naturally gets reduced and the $\mathrm{CO}_{2}$ concentrations may increase due to the depreciation of the absorbing capacity.

B) The absence of trees will result in the increase in the respirable suspended particulate matter ( $\mathrm{rspm}-2.5$ microns) and the total suspended particulate matter (including 10 and 2.5 microns) due to the lack of adsorption by the leaves of the trees.

C) The concentration of the certain pollutants like $\mathrm{so}_{2}$ and $\mathrm{no}_{\mathrm{x}}$ which are released due to industries and traffic will be increasing from the existing levels due to the lack of green belt and avenue plantation.

D) The high transpiration by the leaves will get reduced and the moisture levels decrease in the biosphere.

E) The increase in radiation will be caused due to the loss of plant canopy and the direct hitting of sun rays to the earth which will be reradiated into the surrounding environment.

F) The heat island effect phenomena will be seen in the areas where high-rise buildings are located and concrete pavements and tar roads exists due to the continuous radiation and adsorption and re-radiation by the concrete structures.

G) It also may contribute to the erosion of soils heavily and reach the surface water runoffs during heavy rains and cause sedimentation of drains or silting of natural nallas.

H) There is a likely possibility of occurring of landslips or landslides in the hilly slope areas due to the lack of soil binding resulting in the mass destruction of trees.

I) During the rainy season for at least next 2 years there is a likelihood of low recharge of the ground water aquifer and reduction in the recharge in the aquifer due to the heavy surface runoff and non detention of rain water.

2. Problems due to the waste accumulated:

A) The loss of tree cover accumulated and detained at certain pockets and grounds which may catch fire and cause damage to the environment by releasing different organic gases. 
B) The wood collected may be disposed off in stages to the following industries.

i) the soft wood required for the paper mills can be sorted out and the parties may be contacted immediately to lift the wood for utilization.

ii) hard wood may be disposed off to biomass based energy power plant who will shred them and burn to produce the power.

iii) at any cost the biomass and the waste accumulated should not be incinerated in public as it may lead to production of dioxides or volatile organic carbons which may result in asthma and upper respiratory problems in children and aged.

3. Municipal solid wastes and hospital wastes:

Visakhapatnam will be facing a severe problem in handling the municipal solid waste and hospital waste accumulated and mixed up with the biomass wastes. Hence separate teams should work to clear by segregating the municipal solid wastes as they putrefy and spoil the natural bio-waste. It is observed that the wastes are mixed and dumped which may result in leaching of organic acids and percolate into the sandy soil strata and cause pollution to the ground water in the future. So immediate action of removing the dump grounds used to disposed off wastes by utilizing it appropriately.

4. Water supply systems:

A) Care should be taken in supplying the municipal water to the needy as there is a likehood of contamination of municipal water through broken pipes. Monitoring of water quality should be stepped up and the areas may be identified where the contamination is detected.

B) People also should be educated and informed about the possibility of contaminated water and proper chlorination should be done at community level or at the individual level by supplying the appropriate chlorination mechanisms.

C) In areas where high ground water table occurs, pumping should be avoided in order to control the contamination of aquifer due to percolation of the contaminated surface water.

5. Spread of infectious diseases:

A) Due to the lack of protective green cover and as predicted increase of suspended particulate matter in the air there is a likelihood of increase in the viral infections to the eyes, throat and allergy to the skin. This happens because of air borne virus particles which reach the humans extensively due to the lack of adsorption by trees or lack of impediments.

B) It can be expected that the future rains will bringing the sediments and mix up with the drinking water or the percolation into the aquifer may lead to several water borne diseases like cholera and dysentery

6. Prevention and protection measures to combat the above impacts of Hudhud:

- The protection of plants which are injured by using their stems and twigs should be restored which are not uprooted from the ground. A special nourishment and provision of water should be provided in order to relive in the half dead plants. Measures also may be taken to straighten up certain plants which leaned to the ground and rehabilitate them by supporting to stand erect appropriately.

- $\quad$ it is now necessary to Visakhapatnam to have certain fountains to the middle of high raised buildings or in the centrally located places to reduce the impacts of heat island as it is done in many western countries.

- To avoid planting of trees close to the buildings and to the electric poles and this proved to be damage causing to the existing system. The right thinking would be to have them in large parks where the people can relax in the evenings or which may act as artificial lungs to restore the balance of oxygen to the carbon dioxide.

- It should be made mandatory to the entire building owner either old or new to go for white paints which reflect the radiation instead of absorbing into the concrete to avoid the heat island effect.

- The construction of houses on hill slopes should be avoided unless until appropriate measures of retaining wall are built by the house owners. The illegal construction on the hill slopes should totally be avoided and people who occupied may be rehabilitated from the vulnerable areas identified after thorough testing of the soil strata.

- The local authority should implement strictly the construction of rain water recharging pits and monitor them through the third party for harnessing the advantages of increasing the ground water levels. It is also necessary to identify the surface drains which bring in the rain water mixed with the drain water into a community recharge pits with appropriate treatment of the drainage.

- The solid waste should be given top priority as it may also be instrumental in spreading the diseases and promoting the rodents, pigs which are the reservoirs of many different parasitic diseases. The solid waste also promotes the fly nuisance which is also cause for spreading the diseases in the community where small food joints are the sources of spreading the diseases. It is advised that the people should avoid eating in the public eateries till the conditions improved in the local environment. The local authorities should insist the refraining of sweet meats in public by discouraging the sale of food in the small eateries.

- The local authorities and the administration should propagate the avoiding of any fireworks which are air borne like rockets, lanterns or any fireworks which may lit fire to the heaps of piled dry solid waste dumped in large quantities in the grounds. It may also lit fire in localities where still the debris and tree waste are not removed so far.

- It is observed that at several places the mixed solid waste with the tree twigs are burnt leading to spread of smoke in the localities. It should be advised to the locals or the sweepers not to indulge in letting the fire to the solid waste.

- As Visakhapatnam is identified as a smart city the communication facilities should be improved and in 
the absence of electronic media and print media a public address system or community net work system should be developed with the help of electronics engineers or with the help of ham radio system.

- The hospitals and the doctors should gear up to the hidden danger of spread of diseases both viral and bacterial and treat the patients immediately by identifying them. The medical outlets are also to be advised to keep ready the medicines in order to face the demanding situation for the next 2 to 3 months.

- The locals should adopt themselves to live with the changing environmental scenario by adopting the following:

I)during the high temperatures in the area the people should put on cotton dresses specially white in colour and cover their heads with caps and protecting their eyes with glasses which have the UV filtering capacity. They should also avoid moving during the mid day as the temperatures and radiation will be high.

Ii) the locals should make it a habit to put on nose masks to avoid the dust entering into their nose.

Iii) they should drink lot of water to detoxify or to avoid dehydration.

\section{CONCLUSIONS}

The great loss of tree cover and change in the local conditions due to Hudhud in the city of Visakhapatnam impacts local life and environment. Suggestions were given in the above paper to benefit of the locals and to the administration to rebuild the environment. These suggestions include improvements to the current land, water and solid waste management practices. These measures can improve the changed environment in Visakhapatnam post cyclone Hudhud.

\section{REFERENCES:}

1. Hansen J, et al. (2007) Dangerous humanmade interference with climate: a GISS modelE study. Atmos Chem Phys 7:22872312.

2. Manabe S, Stouffer RJ (1980) Sensitivity of a global climate model to an increase of $\mathrm{CO} 2$ concentration in the atmosphere. J Geophys Res 85:5529-5554.

3. Ramanathan V, Feng Y (2008) On avoiding dangerous anthropogenic interference with the climate system: formidable challenges. Proc Natl Acad Sci USA 105:14245-14250

4. Robert W. Howarth, Renee Santoro, Anthony Ingraffea, "Methane and the greenhouse-gas footprint of natural gas from shale formation"

5. Susan Solomon, Gian-Kasper Plattner, Reto Knutti and Pierre Friedlingstein, "Irreversible climate change due to carbon dioxide emissions" 